\title{
IMPACT OF COOPERATIVE SOCIETIES SAVINGS SCHEME IN RURAL FINANCE: SOME EVIDENCE FROM NIGERIA
}

\author{
Onafowokan O. Oluyombo *
}

\section{ABSTRACT}

This paper examines the extent to which savings products offered by cooperative societies in some parts of Nigeria meet the financial needs of the rural dwellers. The study used the data from interviews and focus group discussions from randomly selected members of cooperative societies in six local governments. The data are analzed using percentages, content analysis and quotation. The study found that the savings product helps to inculcate a good savings habit among the participants because they find it easier to save now than when they were introduced to the program. The members also developed self esteem as "part owners" of the program because of the compulsory savings that they participate in, and they do not want the program to collapse. Members are also satisfied because they are able to save in the scheme which helps them to reduce their expenses on frivolous spending such as leisure drinking and acquisition of more wives. The members' inability to withdraw from their savings when in financial need, except on cessation of membership, was found as the drawback of the program.

Keywords: cooperative societies, rural finance, savings, social capital

JEL: B26, D14, D61, D71, G23

\section{INTRODUCTION}

Rural dwellers are largely neglected by formal financial institutions because they have no access to institutional credit due to collateral requirements, complex procedures, poor communication, and inadequate banking network in the rural areas (Haque and Yamao, 2008). In addition, financial institutions may find it difficult to understand the economic pattern of rural people and unable to fashion out products and services to meet their needs. The low educational attainment of rural dwellers may be another impediment in having formal financial providers in rural areas. The World Bank (2000) affirms that the main reasons banks are located in urban centers in Nigeria are because of the high risk of operating in rural areas, lack of adequate infrastructure - roads, water, telephone service, and electricity - and poor returns on banking investment in rural areas. Formal banks hardly lend to the rural people because they lack collateral that they could offer as security for loans (Nathan et al., 2004; Tsai, 2004). Larocque et al. (2002) reported that the rural people are unable to patronize the formal banking system due to requirements for opening an account which most rural dwellers cannot meet.

Microfinance programs that lay emphasis only on lending will likely be unable to serve or benefit the teeming poor who may wish to save but do not necessarily wish to borrow (Buckley, 1997). Members must save regularly over a stated period of time before loan is given based on the amount of saving the member has with the cooperative. According to Larocque et al. (2002) savings deposits made available to cooperative members, who 
are often neglected by some microfinance institutions, adding an important dimension of risk reduction to the cooperative members because their results show that clients save to avoid theft and to reduce crime level in the community, because of existence of cooperatives. Hence, financial intermediation is not complete with availability of credit without the platform to mobilize savings from the poor. Nathan et al. (2004) stated that to minimize transaction costs, microfinance institutions tend to be urban based, leaving the poor in the rural areas under-served. This is an evidence of dereliction of duty and it can be noticed more in Nigeria where the majority of the microfinance banks that are meant to serve the poor are located in the high brow areas of the cities and serve the rich and medium income earner instead of the poor (Oluyombo, 2010). In an economy with the above scenario, the poor are left with two options: they either patronize the informal finance providers with all their stringent conditions or decide to stay away from the financial system entirely.

The findings on the effect of cooperative savings service on the members from the previous studies are inconclusive and therefore require further investigation. Furthermore, none of the studies was conducted among members of cooperative societies located in rural areas of developing nations where there is no electricity, tarred road, and government water supply which are the focus of this study. This study is significant because it focuses only on members promoted cooperative societies in rural areas without support from donor and government, while none of the previous studies used only members promoted cooperatives. For example, Member/self promoted, government sponsored and program promoted cooperatives were used by Simkhada (2004). Sharma et al. (2005) used two self promoted and two program promoted cooperatives, while the program promoted cooperatives enjoy support in form of grants from donors. Ghosh and Maharjan (2001) used government sponsored cooperatives, while Wanyama et al. (2008) used multiple ownership cooperatives which include a donor funded cooperative. This study seeks to update the role of cooperative societies savings to members' financial needs in rural areas. The only proposition for this study will investigate the relationship that exists between participation in cooperative societies and the individual members. This is stated below.

Proposition: Cooperative savings service satisfies the financial needs of their members.

\section{RELATED LITERATURE}

Microfinance programs are solutions to bridge the gap between the supply and demand for rural finance (Tsai, 2004) and the programs could be formal, informal or semi-formal, depending on the ownership and regulative structures. Due to the lack of formal financial providers in rural areas, semi-formal and informal financial providers such as cooperatives, rotational savings associations, self-help groups, and money lenders are major providers of financial services in rural areas (see Oluyombo, 2012: 9-25). The informal financial sectors are those financial providers that cannot be classified as a separate legal entity since they are neither controlled nor regulated by the government (Oluyombo, 2013). For example, the cooperative societies and the rotational savings associations are among the oldest and most popular savings schemes in developing nations (Gugerty, 2007; Oluyombo, 2010). However, the operation of rotational savings associations make it risky and inflexible (Gugerty, 2007) because each saver in the association collects a lump sum of other members' savings at rotational interval.

The patronage for cooperative societies as a form of informal financial arrangement according to Tsai (2004) is due to lack of 
access to formal credit even when rural dwellers keep their savings in formal financial institutions. This also makes the rotational savings association participation high in Africa (Gugerty, 2007). Cooperatives are relevant in rural finance because of the gap that exists between the demand and supply of formal bank loan which Tsai (2004) refers to as supply leading economics. This may not be applicable to all rural areas because in developing nations, banks are located outside the rural areas (Oluyombo, 2012), which makes it impossible for rural dwellers to participate in formal financial services. Where banks are located in rural areas, such banks lack the necessary experience to lend to rural clients (Tsai, 2004) who are unable to provide collateral for such loans. It is in this regard that the activities of informal finance providers in rural areas tend to be on the increase as an alternative to formal banking services. One of such informal finance providers is the cooperative society. This study defines a cooperative as a voluntary open association established and owned by people of like minds who come together to form an organization called cooperative society without government or program funding. Its purpose is primarily the mobilization of funds in form of savings from the members, which guarantee access to loan facility to such members who meet the minimum savings period requirement of the program. It also provides the ability for a loan application in order to improve the economic conditions of members of the association with little or no control from the government. As a voluntary association, a member is free to join or cease to be a member at will, based on the rules guiding the cooperative.

The impact of four savings and credit cooperative societies which consist of two self promoted, one program promoted, and one government sponsored cooperatives located in both the rural and urban areas was carried out by Simkhada (2004). The researcher reported that the cooperatives used compulsory savings to develop thrift among members and as a result, the members developed capacity to save. Nathan et al. (2004) found that savings help rural finance clients to determine their loan amount and how they save in the program. The findings suggest that the poor people are not only interested in credit but also how to save their money. It is not the credit obtained that raises the poor out of poverty but their ability to save from income generated from the use of the credit given (Buckley, 1997). A person that finds it very difficult to save may eventually consume both his capital and income because credit alone may not be enough to deliver the poor from poverty.

A study of an employee and a community based cooperatives by Eisenhauer (1995) found that the number of members that keep savings in a postal savings account decline within two years while savings in the cooperative was on the increase. Fifty-four percent (54\%) save in order to qualify for loan while $20.4 \%$ save to benefit from life and debtors insurance. Eight percent $(8 \%)$ save because it is convenient, $3.5 \%$ for safety and $3.5 \%$ because of higher rate of interest. Larocque et al. (2002) found that cooperative members are willing to save and that $49 \%$ actually save to provide security against theft, $28 \%$ to avoid useless expenses, while 15\% save against fire. Thirteen percent (13\%) save in order to have access to loan. Financial intermediation is therefore not complete with availability of credit without the platform to mobilize savings from the poor, because cooperatives are meant to provide savings and loan services to their members (Oluyombo, 2012). A study in Russia by Lohlein and Wehrheim (2003) reported that instead of savings, members increase their equity in the scheme because cooperatives in Russia are forbidden from accepting savings. Wanyama et al. (2008) used qualitative data from eleven African countries to determine 
the impact of cooperatives on poverty reduction among households. The research found that the program enables members to accumulate savings. Most cooperatives in their study are formal in nature and they are based in urban centers, owned by educated people who are employees of educational institutions. Sharma et al. (2005) reported an increase in savings habit among members between three years when the first study and the last study were conducted.

Oke et al. (2007) result shows that savings is not a new thing to microfinance participants. This position was also supported by the findings of Idowu and Salami (2011). However, Idowu and Salami (2011) reported further that when entrepreneurs borrow from microfinance banks, they find it difficult to save with the bank during the loan repayment period. This was traced to the high interest rate of the microfinance banks which is higher than commercial banks rate. As a result, $85.72 \%$ of the clients' savings do not increase while repaying their loans. The ability of cooperative societies to survive requires that its members should participate in regular savings and that loan procurement should not be the main attraction for joining the program. Although loan is essential for the poor, it can also be argued that availability of loan without regular financial commitment by the loan receiver in the form of savings will hamper the sustainability of such program. Edgcomb and Garber (1998) documented that clients that engage in the program savings products develop a good savings habit which they find difficult to do before joining the program. By linking credit to savings in their lending methodology, microfinance institutions inculcate a culture of saving among the clientele and savings play a critical role in the development process for financing investment (Nathan et al., 2004). Adjei et al. (2009) found a positive relationship between loan amount and savings deposit even when only $10 \%$ of loan amount is expected to be in the beneficiary savings account.

\section{METHODOLOGY}

The study used cross sectional data from personal interview and focus group discussion (FGD). The interview and FGD guides were translated into the local language (Yoruba) of the respondents in order to gather accurate responses to the questions. For example, cooperative societies are called "egbe alaje seku" in the local language of the respondents. This study was conducted in Ogun State, Nigeria which consists of 20 local governments divided into three senatorial districts. The population for the study are cooperative societies that are not registered with the State goverment. Stratified and random sampling techniques were used as follows: Two local governments that are more rural - based on Nigeria's poverty index - were selected in each senatorial district for study. Two cooperatives from the six local governments were selected randomly for the FGD, while six members from each cooperative were randomly selected to participate. Samples for the interview were drawn from two cooperatives each from the six local government area with four members randomly selected from each cooperative. Therefore, the proposed sample prior to the field work is 72 for FGD and 48 for interview. The researcher conducted interviews with 18 males and 30 females. The initial plan was to hold two FGDs in each local government area, but this was not possible because of the variation in market days of either the communities used or neighboring villages where the selected participants trade. As a result, six FGDs took place with 42 participants comprising of 20 males and 22 females. The actual number of participants at the FGD ranged from 6 to 8 .

The interviews were conducted on a one-onone basis but the cooperative officials were not allowed to participate in the interviews 
and FGDs. These precautions were undertaken to avoid bias and to enhance the validity and reliability of the study by reducing subjectivity and third party interference. The interview comprised of structured open ended questions, to allow participants to describe their personal experiences with the cooperative and to enable them to speak without any restriction using their own words. Both the interviews and the FGDs were jointly documented using a tape recorder and interview guide record sheets. The recorded discussions from the interviews and the FGDs were transcribed and later translated into English. These transcriptions and translations were then compared and reviewed with the interview notes. The data derived from the interviews and the FGDs were reported and analyzed using frequency, percentages, and content analysis as necessary.

\section{FINDINGS AND DISCUSSION}

\subsection{Demographic Characteristics}

Among the forty-eight interviewees, ten participants have been with the cooperative for more than six years, while twenty six members have put in between two and five years into the program (see Table 4.1 below). There are twelve of them who are within one year membership. The majority of the interviewees are female (62.5\%) while males accounted for $37.5 \%$. The marital status reveals that $66.67 \%$ are married and that $8.33 \%$ are either separated or divorced. The widowed and the single accounted for $12.5 \%$ each.

Table 4.1. Interviewees' Demographic Information

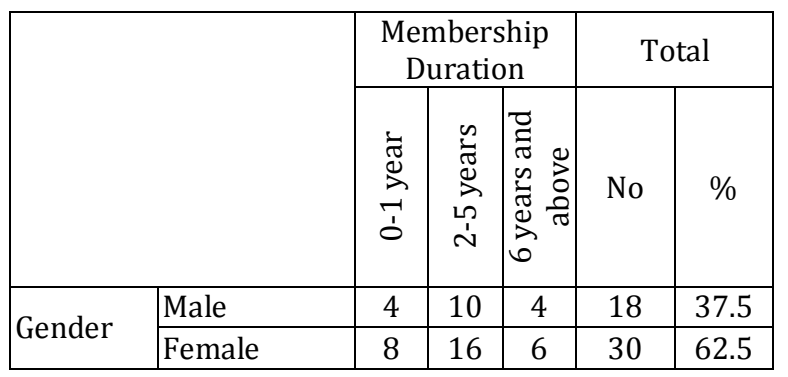

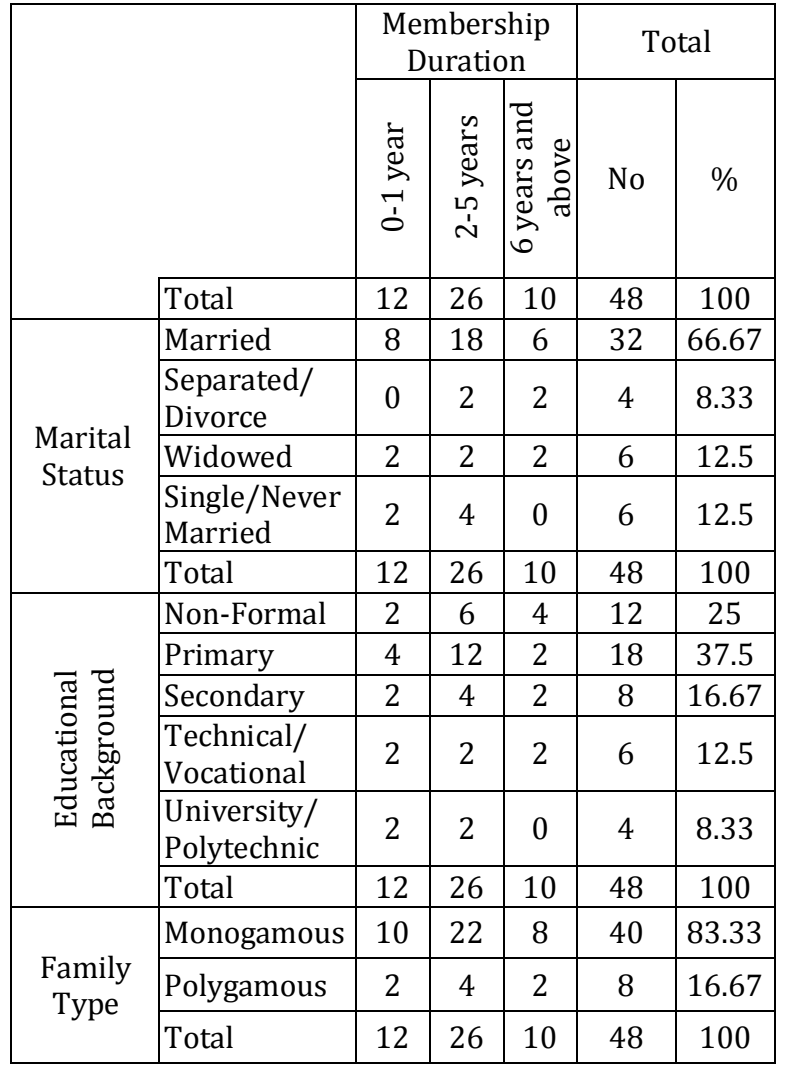

The result of the interviewees' educational attainment shows that $25 \%$ of them do not possess any formal education while 37.5\% holds a primary school certificate. Some $16.67 \%$ have secondary school education while those with technical/vocational education account for $12.5 \%$. Only $8.33 \%$ of the respondents have tertiary institution qualification from either the polytechnic or the university. Some $62.5 \%$ of the participants are core illiterates based on Nigeria's minimum educational attainment for classification of illiterates. This type of result is not surprising since the study was conducted among rural dwellers who may not find it easy to improve their educational attainment. Moreover, the study locations with the lack of access to basic amenities could be used to support the result of participants' low level of educational qualification and the reason for conducting the study in their local language (Yoruba). This study also examines the family types of the interviewees and found out that $83.33 \%$ practice monogamy while $16.67 \%$ belong to the polygamous family set up. This data shows 
an even distribution of the demographic information as a true resemblance of the rural people. It therefore implies that the sample is a good representative of the population. The researcher does not see any reason to justify the collection of demographic information such as educational qualification from the focus group of discussants because doing so may expose any of the discussants to shame and ridicule. The discussants are selected based on their membership of the cooperative irrespective of their membership position and duration in the program.

\subsection{Impact Traceable to Savings}

In a cooperative society, savings have to do with putting aside a fixed or flexible sum of money into the program at interval in favour of the member. Savings also play a critical role in development process (Nathan et al., 2004) which may lead to a better and improved savings habit and ability to manage money for productive use. The experiences of the interviewees and focus group discussants based on their involvement in savings product of the cooperative are stated below.

\subsubsection{Interview Result}

The interview result in Table 4.2 below shows that 30 out of 48 participants like the compulsory savings of the program because it has helped them to improve their savings habit as they find it easier to save now than when they first joined the cooperative.

Table 4.2. Interviewees' Response

\begin{tabular}{|l|c|c|}
\hline & $\begin{array}{c}\text { No. } \\
\mathrm{n}=48\end{array}$ & Percentage \\
\hline $\begin{array}{l}\text { Compulsory savings helps to } \\
\text { inculcate a saving habit into } \\
\text { my life and I find it very } \\
\text { easier to save now than } \\
\text { when I newly joined the } \\
\text { cooperative. }\end{array}$ & 30 & 62.5 \\
\hline $\begin{array}{l}\text { None withdrawal of savings } \\
\text { when in financial need } \\
\text { except on cessation of } \\
\text { membership. }\end{array}$ & 28 & 58.33 \\
\hline The use of savings as a & 32 & 66.67 \\
\hline
\end{tabular}

\begin{tabular}{|l|c|c|}
\hline & $\begin{array}{c}\text { No. } \\
\mathrm{n}=48\end{array}$ & Percentage \\
\hline $\begin{array}{l}\text { prerequisite for accessing } \\
\text { loan. }\end{array}$ & & 54.17 \\
\hline $\begin{array}{l}\text { The use of savings as } \\
\text { determinant for loan amount } \\
\text { made me to increase my } \\
\text { savings and reduce } \\
\text { unimportant expenses. }\end{array}$ & 26 & 70.83 \\
\hline $\begin{array}{l}\text { Savings make me a true "part } \\
\text { owner" of the cooperative } \\
\text { hence I am free to express } \\
\text { my opinion on any area of } \\
\text { discussion on the program at } \\
\text { our meetings. }\end{array}$ & 34 & \\
\hline
\end{tabular}

Twenty-eight (28) interviewees which constitute $58.33 \%$ are delighted with none withdrawal nature of their savings when in financial needs except if they want to withdraw their membership from the cooperatives. This may be possible because cooperative serves as an alternative to banks to provide financial transactions in form of savings and loans (Larocque et al., 2002). A number of $66.67 \%$ are better off from the savings product because savings are used as prerequisite for accessing loan. They were delighted that they save; hence they are qualified to take loans from the program when needed. Twenty-six (26) out of 48 respondents (54.17\%) experience the positive impact of savings because the amount saved determines the amount of loan to be given. This conforms to Nathan et al. (2004) that rural finance clients are requested to save an amount in advance as a proportion of loan to be taken. The result suggests that the higher the savings the higher the amount of loan that can be given. This is an example of equality and it can encourage those with meagre fund to save, since the reward of such savings is a higher amount of loan when needed.

The benefits of savings to $70.83 \%$ of the interviewees are that it makes them to be "joint owners" of the cooperative. This affords them the privilege to freely express themselves on any issue about the scheme at the cooperative meetings. This brings about self esteem and sense of belonging among 
members. This could also lead to less default on loan since members see themselves as "joint owners" and as such would not want the scheme to collapse because their savings may be lost if the cooperative ceases to exist. This supports the social capital theory (Basargekar, 2010) and the circle of social capital theory (Oluyombo, 2012) that the effect of membership of financial association such as cooperatives is the collective responsibility that helps for better loan repayment. This impact has a way of protecting the cooperative from external influence because the members have equal voting right and there would likely be no special importance attached to any member or office.

A number of $54.17 \%$ of the interviewees said the use of savings as determinant for loan amount made them to increase their savings and reduce frivolous spending such as leisure drinking, acquisition of more wives, and lavish entertainment of guests. A relative result was documented by Eisenhauer (1995) that cooperative members reduce their savings in postal savings account and increase their savings with the cooperative, while Larocque et al. (2002) reported that $28 \%$ of members saved to avoid useless expenses.

\subsubsection{Focus Group Discussion Result}

The results of the FGD are stated in Table 4.3 below. The result only summarizes what the discussants mentioned and agreed upon.

Table 4.3. Focus Group Discussion Summary Results

\begin{tabular}{|l|l|l|}
\hline $\begin{array}{l}\text { 66.67 percent } \\
\text { 4 of } 6 \text { groups) }\end{array}$ & Disliked & $\begin{array}{l}\text { None withdrawal of } \\
\text { savings in emergency } \\
\text { situations when in } \\
\text { financial need }\end{array}$ \\
\hline $\begin{array}{l}\text { 83.33 percent } \\
\text { 5 of } 6 \text { groups })\end{array}$ & Liked & $\begin{array}{l}\text { Use of savings as } \\
\text { condition for accessing } \\
\text { loan }\end{array}$ \\
\hline $\begin{array}{l}66.67 \text { percent } \\
\text { (4 of } 6 \text { groups })\end{array}$ & Liked & $\begin{array}{l}\text { Amount of savings } \\
\text { being used as a } \\
\text { determinant for the size } \\
\text { of loan that may be } \\
\text { obtained }\end{array}$ \\
\hline
\end{tabular}

\begin{tabular}{|c|c|c|}
\hline $\begin{array}{l}83.33 \text { percent } \\
(5 \text { of } 6 \text { groups })\end{array}$ & Liked & $\begin{array}{l}\text { Savings because it } \\
\text { makes them to be "joint } \\
\text { owners" of the } \\
\text { cooperative and they } \\
\text { are free to express their } \\
\text { opinion on any issue of } \\
\text { the program. }\end{array}$ \\
\hline
\end{tabular}

From the FGD result above, four consequences of savings to individuals' well-being were discovered. A number of $66.67 \%$ frown at the inability to withdraw from savings when in financial need. The cooperative has no provision for emergency loan and this has militated against majority of their members during the period of emergencies such as illness, accidents and burial rites for immediate and extended family members. This contradicts Wanyama et al. (2008) that emergency loans are given by cooperative with shorter repayment period. Four out of six groups wish they could access part of their savings to meet the aforementioned emergencies rather than recourse to other informal sources such as friends, families and neighbors.

The discussants believed that savings do not allow members to either be pushed aside or underrated when issues about the scheme are discussed at their meetings. This should discourage dormant membership since everybody contributed to the funding of the program in the form of savings. Although this may not be possible at all times because other factors such as consistency of savings may warrant members being addressed in a way he or she may not like. But a member is certain that his/her personal ego cannot be undermined when issues are raised. This could help to checkmate the executives when directing the affairs of the society in order not to subvert the program to the detriment of the members.

A number of $33.33 \%$ wish they could access more loans to meet other financial needs, their savings notwithstanding. This is a natural desire when opportunities for 
investments are available especially for short duration where such loans can be repaid with ease. The use of savings as determinant for loan is acceptable to $66.67 \%$ of the discussants. This may mean that members have to save and, more importantly, the savings must be done in a proper order in case the member needs a loan. This also depicts the ability to develop a good savings habit which may entail the reduction of spending on nonimportant things in order to save more.

The effect of this is that members who are financially disciplined enough to save are likely to show more sense of responsibility in loan repayment and this goes a long way to show maturity in the way money is managed. The cooperative might have imparted on individuals positively in the way they manage their money to achieve essential needs while maintaining a sizeable savings with the program.

\subsection{Discussion of Results}

The result of both the interview and FGD identified the major role played by cooperative in rural finance to individual members. The impact of savings is self esteem because the members see themselves as part owners of the cooperative and cannot be bluffed when issues affecting the cooperative are discussed. This will make the members to protect the interest of the cooperative and ensure the continual existence of the scheme. In spite of Huppi and Feder's (1990) opinion that failure of cooperative society in India, Philippines, and Thailand is due to lack of sense of ownership among the members, this study indicated that savings in the cooperative made the members to be part owners and lead to self esteem. Edgcomb and Garber (1998) found self esteem in their study because the program leads to female members' empowerment. This study' results thus lead to social capital as found in the social capital theory which is achieved through the self esteem derived from being a member of the cooperative. The social capital through self esteem is the effect of participating in the cooperative which results in fulfillment of other non-financial goals that may not be known before a person enrolls the cooperative. Such result is not attainable by a person without the membership at the cooperative.

The savings serve as the major condition for accessing loan from the cooperative. Actualization of individual financial goals through the scheme is enhanced by the amount of money saved in the program. This result is contrary to the findings of Oke et al. (2007) where clients had ready access to loan facilities and Eisenhauer (1995) where 54\% of the cooperative members save to qualify for loan. However, Adjei et al. (2009) found a positive relationship between loan amount and savings deposit even when only $10 \%$ of loan amount is expected to be in the beneficiary savings account. The more a member saves the better for such a person when seeking a loan which propels members to save more especially when they are futuristic in the amount of loan they will require to improve their economic condition for a better standard of living. The role of the cooperative in helping members to accumulate savings helps them to fulfil financial capital which is found in the social capital theory. One can draw the conclusion that cooperative savings provide opportunity to accumulate financial capital, which members found difficult to do before joining the cooperative. This finding supports the social capital theory and also tally with Oluyombo (2013) that financial capital is achievable when the social capital theory is applied to rural finance programs where the participants are members of an association or group such as cooperative societies. This benefit is closely related to the self esteem explained earlier because with members' savings, it will be very difficult, if not entirely impossible, for their loan application to be 
rejected. The savings grant them confidence when in need of loan facility because the basic requirement has been met. This result is contrary to Larocque et al.'s (2002) finding where only $13 \%$ save in order to have access to credit. The difference in results may be due to the use of longitudinal study and the combination of village banks and cooperative societies' clients in their study because the village banks used do not operate compulsory savings scheme, or use the amount of savings as a condition for accessing loan.

If the finding of this study is compared to other formal financial institutions such as banks, the maintenance of savings does not guarantee the availability of loan to a bank customer. But for cooperative members, the contrary is the case. This approach gives members a good level playing field that enables individuals to determine the amount of loan he/she may receive, based on the amount of savings he has in the cooperative which is cumulative in nature since the savings cannot be withdrawn except on cessation of membership. This conforms to findings of previous studies (Nathan et al., 2004; Adjei et al., 2009) that loan amount determines how the participants save. Compulsory savings system of the cooperative that does not specify the minimum or maximum amount to be saved or the pattern of savings, such as daily, weekly or monthly is another impact of savings on individuals. This has helped to inculcate a good saving habit into majority of the members. They find it very easy to save now, irrespective of the amount and the timing, than when they first joined the cooperative. This result suggests that rural people save despite their meager income by participating in cooperative society. Larocque et al. (2002) reported that cooperative members are willing to save. A cooperative also leads to increase in savings habits among members because increase in savings also increases the amount of loan that members can obtain from the cooperative.
This also reduces unnecessary spending such as acceptance of chieftaincy title and acquisition of more wives.

The mandatory savings draw more members to the scheme, first to learn and develop a savings habit, which eventually may become consistent when the members realize the potential benefits of increased savings. The drawback is that some members may save because it is compulsory for them to save in order to obtain the needed loan and not because they are interested in cultivating a savings habit. Despite this, one stands to reason that over time, some of the members may have a change in their savings habit that may propel them to save not because of the loan they are expecting but because they are partners in progress in the cooperative. Another impact is prevention of withdrawal of member's savings when in financial need except on cessation of membership. Members can visualize what awaits them if they withdraw their membership after a particular period of time and what will be given to their family in case of death, which made the savings a form of social protection and a way of militating against the effect of risk of death which is inevitable. Cooperative as a form of social protection for members reduces their vulnerability in the time of crisis, which prevents them from selling their properties and falling further into poverty. This is possible because the membership of the cooperative will cease on the death of the member with his savings paid to a named beneficiary who may be the spouse of the deceased, the children or a close family member. This implies that any member who needs his savings can voluntarily withdraw from the program. This is contrary to the Nigeria banking system whereby an account holder is free to withdraw from his savings account at will without ceasing to be a customer. However, this impact should be noted in the light of the operational modalities of the cooperative society used for this study 
because members' savings are the major source of funding available to the program. The payment of savings after death, which reduces worry and stress for the members and the immediate family, is in line with the social capital theory that the cooperative is used to build social security for the members.

\section{CONCLUSION}

There is advancement in savings habits of rural people and this can be used as an avenue for the introduction of rural bank to the rural dwellers. This finding is important to the government, academicians and practitioners because if cooperative members can save with the scheme and also enjoy financial intermediation, they can also save with the rural bank where their savings can be withdrawn at will, provided the bank is located nearer to the people. The policy implication will require the review of the current banking policy and regulation by the government to allow for the establishment of rural banks in rural areas. Establishment of rural bank will help to integrate the rural people into the financial system which will also help to reduce the quantity of money outside the banking system.

The finding that cooperative inculcate a good savings habit to the rural dwellers implies that it is not too late for Nigeria to commence a purpose driven rural finance strategic fund to develop rural financial system through the cooperatives, to provide revolving credit to rural dwellers through their respective cooperative, and to integrate the cooperatives into formal rural finance providers for the development and improvement of rural economy. This arrangement may reduce the cost of providing social support for rural people by the government. The study reveals that the scheme replaces the absence of government social security in rural areas because the social security in Nigeria only covers people in paid employment in government registered enterprises. The government may have to either develop a new social security system solely for the rural dwellers or incorporate the rural people into the existing social security policy. In addition, concerted efforts should be made by the government to provide infrastructural facilities such as tarred road, electricity and drinkable water to the rural areas so as to improve their economic well-being. This may impact positively on their business since the time lost due to none availability of these three infrastructural facilities in all the study sites can be channeled to productive use in their enterprises, which may also increase their income, improve standard of living and further reduce poverty as household and enterprise income increases. The findings show that savings leads to self esteem of members because they see themselves as part owners of the scheme. This makes them to protect the interest of the cooperative and also do whatever it takes to ensure the continual existence of the program. The members' inability to withdraw from their savings when in financial need except on cessation of membership was found as the drawback of the scheme. Despite this, the study upholds the research proposition that cooperative savings service satisfies the financial needs of their members.

\section{REFERENCES}

1. Adjei, J., Arun, T. and Hossain, F. (2009) Asset Building and Poverty Reduction in Ghana: The Case of Microfinance. Savings and Development, No. 3, XXXIII, pp. 265291.

2. Basargekar, P. (2010) Measuring Effectiveness of Social Capital in Microfinance: A Case Study of Urban Microfinance Programme in India. International Journal of Social Inquiry, Vol. 3, No. 2, pp. 25-43.

3. Buckley, G. (1997) Microfinance in Africa: Is it either the Problem or the Solution? 
World Development, Vol. 25, No. 7, pp. 1081-1093.

4. Edgcomb, E. L. and Garber, C. (1998) Practitioner-Led Impact Assessment: A Test in Honduras. Washington, D. C.: Management System International.

5. Eisenhauer, J. M. (1995) Malawi Union of Savings and Credit Cooperatives: Member Service Survey. World Council of Credit Unions Research Monograph Series, Number 8.

6. Ghosh, A. K. and Maharjan, K. L. (2001) Impacts of Dairy Cooperative on Rural Income Generation in Bangladesh. Journal of International Development and Cooperation, Vol. 8, No. 1, pp. 91-105.

7. Gugerty, M. K. (2007) You Can't Save alone: Commitment in Rotating Savings and Credit Associations in Kenya. Economic Development and Cultural Change, Vol. 55, No. 2, pp 251-282.

8. Haque, M. S. and Yamao, M. (2008) Can Microcredit Alleviate Rural Poverty? A Case Study of Bangladesh. In: Proceedings of World Academy of Science, Engineering and Technology, December 2008. Vol. 36, pp. 663-671.

9. Huppi, M. and Feder, G. (1990) The Role of Groups and Credit Cooperatives in Rural Lending. The World Bank Research Observer, Vol. 5, No. 2, pp. 187-204.

10. Idowu, A, and Salami, A. O. (2011) Impact of Microfinance Bank on Standard of Living of Hairdresser in Ogbomoso North Local Government of Oyo State, Nigeria. American Journal of Social and Management Sciences, Vol. 2(1), pp. 3440.

11. Larocque, P., Kalala, J. and Gaboury, A. (2002) The Impact of Savings and Credit Cooperatives in Burkina Faso. Ottawa: Developpement International Desjardins.
12. Lohlein, D and Wehrheim, P. (2003). The Role of Credit Cooperatives in Rural Russia. Gloros Policy Paper, June. pp. 1-20.

13. Nathan, F. O., Margaret, B. and Ashie, M. (2004) Microfinance and Poverty Reduction in Uganda: Achievements and Challenges. Economic Policy Research Centre, Research Series No. 41

14. Oke, J. T. O., Adeyemo, R. and Agbonlahor, M. (2007) An Empirical Analysis of Microcredit Repayment in South Western Nigeria. Humanity and Social Sciences Journal, 2 (1), pp. 63-74.

15. Oluyombo, 0. O. (2010) Assessing the Impact of Savings and Credit Cooperatives Among Monthly Income Earners. Journal of Research in National Development, Vol. 8, No. 2b, pp. 407-415.

16. Oluyombo, O. O. (2012) The Role of Cooperative Societies in Rural Finance: Evidence From Ogun State, Nigeria. Unpublished thesis (PhD), De Montfort University, Leicester. United Kingdom.

17. Oluyombo, 0. O. (2013) Impact of Cooperative Finance on Household Income Generation. DLSU Business and Economic Review, Vol. 23, No. 1, pp. 53-65.

18. Sharma, N., Simkhada, N. R. and Shrestha, R. (2005) Impact Assessment of SACCOSs in Nepal's Hill Districts: Findings of an Action Research. Kathmandu: Centre for Micro-Finance (Pvt) Ltd.

19. Simkhada, N. R. (2004) Innovations in Nepal's Microfinance Sector and Benefits for Asia - A Case Study of Four Savings and Credit Cooperative Societies operating in the Hills of Nepal. Paper Presented to the Workshop on Sharing Microfinance Resources and Knowledge in South Asia. February 24.

20. Tsai, K. S. (2004) Imperfect Substitutes: The Local Political Economy of Informal 
Finance and Microfinance in Rural China and India. World Development, Vol. 32, No. 9, pp 1487-1507.

21. Wanyama, F. O., Develtere, P. and Pollet, I. (2008) Encountering Evidence: Cooperatives and Poverty Reduction in Africa. Working Papers on Social and Cooperative Entrepreneurship, WP-SCE 0802
22. World Bank (2000) Financing Nigeria's Rural Micro and Small-Scale Enterprises. Rural Development 2, Africa Region. Report No.: 19973-UNI, May 11. 